University of Wollongong

Research Online

Faculty of Engineering - Papers (Archive)

Faculty of Engineering and Information

Sciences

$1-1-2012$

\title{
Phase development in carbothermal reduction and nitridation of ilmenite concentrates
}

Sheikh A. Rezan

University of New South Wales

Guangqing Zhang

University of Wollongong, gzhang@uow.edu.au

Oleg Ostrovski

University of New South Wales

Follow this and additional works at: https://ro.uow.edu.au/engpapers

Part of the Engineering Commons

https://ro.uow.edu.au/engpapers/5279

\section{Recommended Citation}

Rezan, Sheikh A.; Zhang, Guangqing; and Ostrovski, Oleg: Phase development in carbothermal reduction and nitridation of ilmenite concentrates 2012, 381-388.

https://ro.uow.edu.au/engpapers/5279

Research Online is the open access institutional repository for the University of Wollongong. For further information contact the UOW Library: research-pubs@uow.edu.au 


\section{Sheikh A. Rezan, Guangqing Zhang and Oleg Ostrovski* \\ Phase Development in Carbothermal Reduction and Nitridation of Ilmenite Concentrates}

\begin{abstract}
The phase development in the course of carbothermal reduction and nitridation of ilmentie concentrates and synthetic rutile was studied in temperature programmed reduction (623-1873 K) and isothermal reduction experiments. Ilmenites and synthetic rutile were reduced in a tube reactor with continuously flowing hydrogennitrogen mixture or pure nitrogen. The rate and extent of reduction were monitored by online off-gas analysis. Samples reduced to different extent were subjected to XRD and SEM/BSE analyses. Pseudorutile and ilmenite were the main phases in ilmenite concentrates; rutile was the main phase in synthetic rutile. Pseudorutile was first converted to ilmenite and titania which occurred at temperatures below $623 \mathrm{~K}$; iron oxides in ilmenite were quickly reduced to metallic iron. Titania was reduced to titanium suboxides and further to titanium oxycarbonitride. Reduction of ilmenites and synthetic rutile in hydrogen-nitrogen mixture was much faster than in pure nitrogen. The rate of conversion of titanium oxides to oxycarbonitride was affected by iron content in the ilmenites. The rate of reduction increased with increasing iron content in ilmenite (decreasing grade) when ilmenites were reduced in the hydrogen-nitrogen gas mixture, but decreased with decreasing ilmenite grade in reduction experiments in nitrogen; reduction in nitrogen was the fastest for synthetic rutile. The difference in the reduction behaviour was attributed to different chemical compositions and morphologies of ilmenites of different grades.
\end{abstract}

Keywords: ilmenite, reduction, nitridation, phase development

$\operatorname{PACS}^{\circledR}$ (2010). 81.20.Ka

Sheikh A. Rezan: School of Materials Science and Engineering, the University of New South Wales, UNSW SYDNEY, NSW 2052, Australia Guangqing Zhang: School of Mechanical, Materials and Mechatronic Engineering, University of Wollongong, Northfields Avenue,

Wollongong, NSW 2522, Australia

*Corresponding author: Oleg Ostrovski: School of Materials Science and Engineering, the University of New South Wales, UNSW SYDNEY, NSW 2052, Australia

\section{Introduction}

Production of titania white pigment and metal titanium include processing of titanium minerals to titanium tetrachloride. Chlorination of titanium dioxide is carried out almost exclusively by fluidised-bed process, which requires high temperature of 1073-1373 K, and uses petroleum coke $\left(0.25-0.4 \mathrm{~kg} / \mathrm{kg} \mathrm{TiO}{ }_{2}\right)$ as the reducing agent. Existing technology for titanium tetrachloride production requires minerals of high quality, with low impurities level, which are processed prior to chlorination to synthetic rutile or $\mathrm{TiO}_{2}$-rich slag.

Titanium oxycarbonitride can be chlorinated at low temperatures. Mostert et al. [1, 2] reported that carbonitride produced by reduction/nitridation of titanium oxide from ilmenite and titanium slag was chlorinated at 473-773 $\mathrm{K}$. In the low temperature chlorination, impurity-oxides do not chlorinate or chlorinate very slowly [3-5]. This permits selective chlorination of titanium oxycarbonitride, decreases the chlorine consumption and waste generation, and makes the whole technology of ilmenite processing more efficient and environmentally friendly.

This paper examines the carbothermal reduction of ilmenite concentrates of different grades in the $\mathrm{H}_{2}-\mathrm{N}_{2}$ gas mixture and pure $\mathrm{N}_{2}$ with main focus on understanding the development of phases and mechanisms of the reduction process.

\section{Experimental}

The raw materials investigated in this paper include primary and secondary ilmenite concentrates, HYTI 70 and synthetic rutile; they were supplied by Iluka Resources Limited, Western Australia. Their chemical compositions were reported previously [6]. Ilmenite concentrates of different grades are distinguished by titanium and iron contents: iron concentration was the highest (30.5 mass\% $\mathrm{Fe}$ ) and titanium concentration was the lowest (53.9 mass $\% \mathrm{TiO}_{2}$ ) in the primary ilmenite, while synthetic rutile contained only 2.80 mass $\%$ total iron and 92.5 mass $\% \mathrm{TiO}_{2}$. 
The XRD analysis showed that the main phases in primary ilmenite were ilmenite $\mathrm{FeTiO}_{3}$ and pseudorutile $\mathrm{Fe}_{2} \mathrm{Ti}_{3} \mathrm{O}_{9}$, while secondary and HYTI 70 ilmenites also contained rutile. Rutile $\left(\mathrm{TiO}_{2}\right)$ was the major phase in the synthetic rutile. Chemical analysis showed that synthetic rutile contained titanium suboxides equivalent to 12.1 mass $\% \mathrm{Ti}_{2} \mathrm{O}_{3}$. Some particles of synthetic rutile also contained metallic iron, which was identified in optical images and confirmed by EDS analysis. The particle size for all ilmenite concentrates and synthetic rutile was in the range of $(50 \sim 400) \times 10^{-6} \mathrm{~m}$, with an average size of $152 \times 10^{-6}, 167 \times 10^{-6}, 180 \times 10^{-6}$ and $181 \times 10^{-6} \mathrm{~m}$, for primary, secondary, HYTI 70 ilmenite concentrates and synthetic rutile, respectively.

As received ilmenites and synthetic graphite (99.5\% purity, $<20 \times 10^{-6} \mathrm{~m}$ in particle size) were wet mixed and pressed into cylindrical pellets. The ilmenite-graphite mixtures contained extra graphite to the stoichiometric amount of carbon needed to reduce titanium oxides to titanium carbide, and iron and manganese oxides to metallic state. The contents of other oxides were very low, and they were considered to be unreducible under given experimental conditions. The pellets with a mass of about $2 \times 10^{-3} \mathrm{~kg}$ were $8 \times 10^{-3} \mathrm{~m}$ in diameter and about $12 \times 10^{-3} \mathrm{~m}$ high.

Reduction of ilmenite concentrates and synthetic rutile by graphite in $\mathrm{H}_{2}-\mathrm{N}_{2}$ and $\mathrm{N}_{2}$ gases were studied in a laboratory fixed bed reactor in a vertical tube electric furnace in the temperature programmed reduction (TPR) and isothermal reduction experiments. Experimental set-up and gas system were presented elsewhere [7, 8]. The gases used in the investigation were of $99.999 \%$ purity. The outlet gas was analysed online by an infrared $\mathrm{CO} / \mathrm{CO}_{2} /$ $\mathrm{CH}_{4}$ analyser (Advanced Optima AO2020, ABB, Ladenburgh, Germany).

The reduced pellets were analysed by XRD with Philips X'Pert-Pro MPD diffractometer (PANalytical, Lelyweg, Netherlands) and $\mathrm{CuK} \alpha$ radiation. Oxygen, carbon and nitrogen contents in reduced samples were determined using LECO analyses (TC-436DR oxygen and nitrogen analyser and CS-444 carbon and sulphur analyser).

The extent of reduction was defined as a fraction of oxygen in titanium, iron and manganese oxides removed in the course of reduction, and was calculated based on the gas composition and oxygen and carbon contents of reduced samples. The extent of nitridation was defined as the fraction of titanium in titanium oxycarbonitride which was present as nitride (TiN).

The errors in measurement of oxygen, nitrogen and carbon contents by LECO analyses were $2-3 \mathrm{wt} \%$. The rel- ative errors of calculated extents of reduction and nitridation were dependent on the contents of oxygen, nitrogen and carbon in the reduced samples. In general, the errors of calculated extents of reduction and nitridation were below $1 \%$ and $3 \%$ correspondingly.

\section{Experimental results}

Temperature programmed reduction (TPR) of ilmenite concentrates and synthetic rutile in the temperature interval of $623-1823 \mathrm{~K}$ and isothermal reduction at 1373$1573 \mathrm{~K}$ were studied in the $50 \mathrm{vol} \% \mathrm{H}_{2}-50 \mathrm{vol} \% \mathrm{~N}_{2}$ gas mixture and in nitrogen with gas flowrate $1.5 \mathrm{~L} . \mathrm{min}^{-1}$. The experiments were stopped at different temperatures in TPR experiments, or reduction time in isothermal experiments; the samples were quenched and then characterized to determine the sequence and mechanisms of reduction of the ilmenite concentrates.

\subsection{Temperature programmed reduction in the $\mathrm{H}_{2}-\mathrm{N}_{2}$ gas mixture}

In the temperature programmed reduction (TPR) experiments with primary ilmenite in the $\mathrm{H}_{2}-\mathrm{N}_{2}$ gas mixture, the molar ratio of carbon to oxygen in titanium, iron and manganese oxides (reducible oxides) was 1.43. The plot of oxygen removal rate $\left(\mathrm{mol} \cdot \mathrm{kg}^{-1} \cdot \mathrm{min}^{-1}\right)$ is shown in Figure 1. In this plot, $\mathrm{H}_{2} \mathrm{O}$ and $\mathrm{CO}$ evolutions are combined to give $\mathrm{a}$ reduction rate curve. Figure 2 presents $\mathrm{H}_{2} \mathrm{O}$ evolution in TPR of primary ilmenite in carbothermal reduction and in the absence of carbon in the $\mathrm{H}_{2}-\mathrm{N}_{2}$ gas mixture

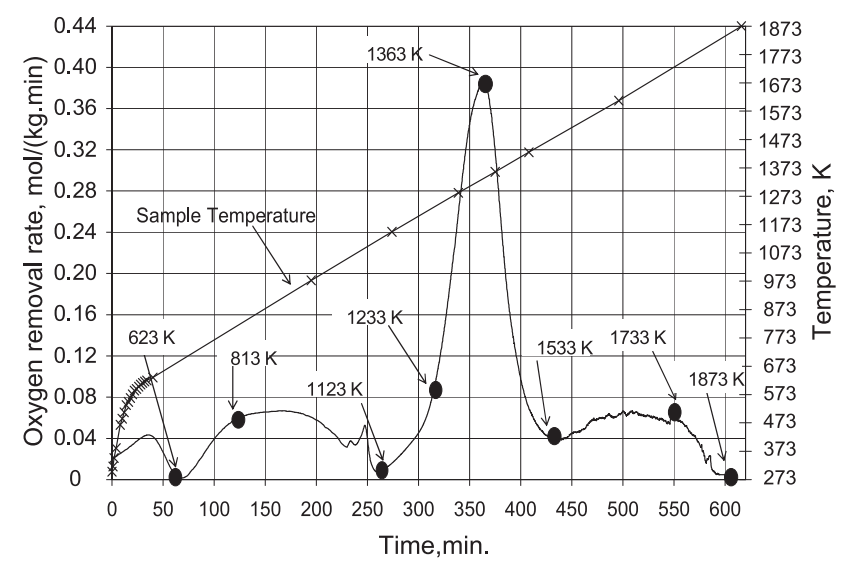

Fig. 1: Temperature programmed reduction of primary ilmenite in the $\mathrm{H}_{2}-\mathrm{N}_{2}$ gas mixture. Temperature was ramped from 623 to $1873 \mathrm{~K}$ at 2 $\mathrm{K} / \mathrm{min}$. Samples in the highlighted points were examined by LECO and XRD. 


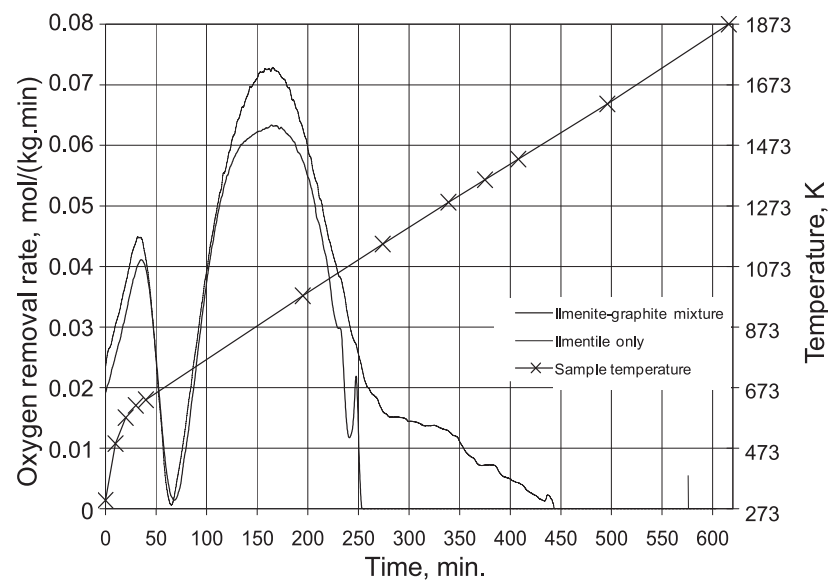

Fig. 2: $\mathrm{H}_{2} \mathrm{O}$ evolution during temperature programmed reduction of primary ilmenite concentrate in the $\mathrm{H}_{2}-\mathrm{N}_{2}$ gas mixture at $623-1873 \mathrm{~K}$.

Iron oxides of pseudorutile and ilmenite were predominantly reduced by hydrogen with evolution of water below $1223 \mathrm{~K}$. The first peak on the $\mathrm{H}_{2} \mathrm{O}$ evolution curve corresponded to the reduction of $\mathrm{Fe}_{2} \mathrm{O}_{3}$ to wüstite, and the second peak was associated with the reduction of wüstite to metallic iron. Hydrogen was also involved in the reduction of titania to titanium sub-oxides, although to much less extent in comparison with reduction of iron oxides. In the reduction experiment with $\mathrm{H}_{2}-\mathrm{N}_{2}$ gas mixture in the absence of carbon, water vapor in the off-gas was detected at higher temperatures, up to $1518 \mathrm{~K}$. This means that in the carbothermal TPR at temperatures above $1223 \mathrm{~K}$, water reacted with carbon forming $\mathrm{CO}$ and hydrogen.

CO evolution started at $1063 \mathrm{~K}$ with formation of two peaks, at $1363 \mathrm{~K}$ and $1713 \mathrm{~K}$. XRD analysis of samples taken at points shown in Figure 1 is presented in Figure 3.

Pseudorutile $\mathrm{Fe}_{2} \mathrm{Ti}_{3} \mathrm{O}_{9}$ was converted to ilmenite and rutile upon heating a sample to $623 \mathrm{~K}$. Metallic iron was

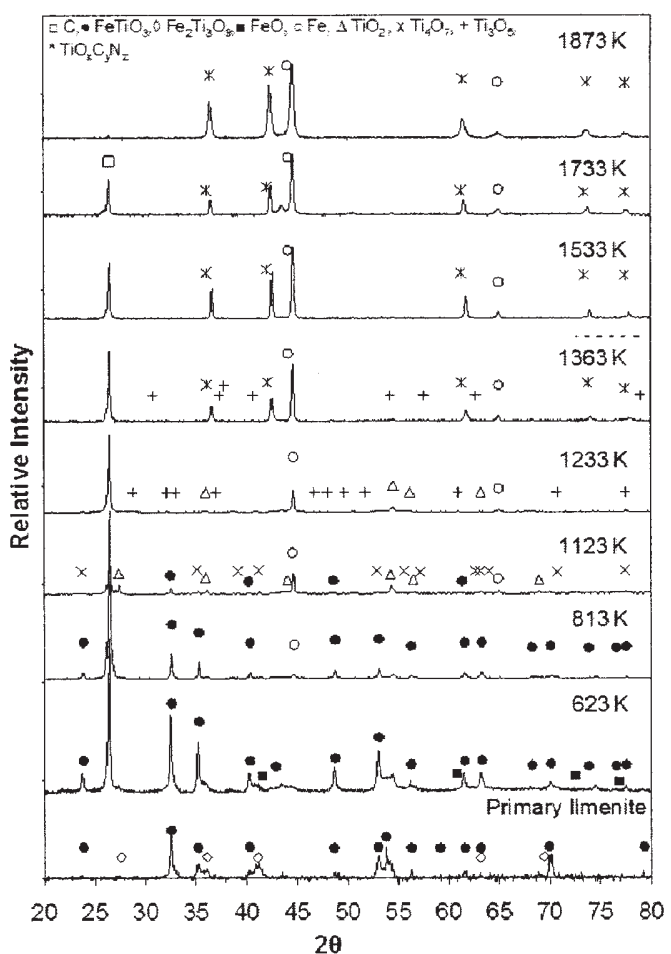

Fig. 3: XRD patterns of primary ilmenite reduced in the $\mathrm{H}_{2}-\mathrm{N}_{2}$ gas mixture to the temperatures labeled in Figure 1.

detected in the sample taken at $813 \mathrm{~K}$. The formation of $\mathrm{TiO}_{2}$ and $\mathrm{Ti}_{4} \mathrm{O}_{7}$ was observed at $1123 \mathrm{~K}$ whereas $\mathrm{Ti}_{3} \mathrm{O}_{5}$ appeared in the sample taken at $1233 \mathrm{~K}$. Ti(O, C, N) was detected at $1363 \mathrm{~K}$ together with $\mathrm{Ti}_{3} \mathrm{O}_{5}$ and metallic iron. No titanium suboxide was observed when the sample temperature reached $1533 \mathrm{~K}$; this sample contained $\mathrm{Ti}(\mathrm{O}, \mathrm{C}$, $\mathrm{N})$, iron and excess carbon. Table 1 shows LECO analysis and phase composition of primary ilmenite reduced by hydrogen in the $\mathrm{H}_{2}-\mathrm{N}_{2}$ gas mixture in the absence of carbon upon heating to $1873 \mathrm{~K}$. Iron oxides were reduced to

\begin{tabular}{|c|c|c|c|c|c|}
\hline Temperature, $\mathbf{K}$ & Oxygen, mass\% & Nitrogen, mass $\%$ & $\mathrm{X}, \%$ & $x_{N}, \%$ & Phases \\
\hline 298 & 24.9 & 0.0 & 0.00 & 0.00 & $\mathrm{Fe}_{2} \mathrm{Ti}_{3} \mathrm{O}_{9}+\mathrm{FeTiO}_{3}$ \\
\hline $298-623$ & 24.4 & 0.0 & 5.8 & 0.00 & $\mathrm{FeTiO}_{3}+\mathrm{FeO}+\mathrm{C}$ \\
\hline $623-813$ & 23.9 & 0.0 & 11.2 & 0.00 & $\mathrm{FeTiO}_{3}+\mathrm{Fe}+\mathrm{C}$ \\
\hline $623-1123$ & 21.7 & 0.0 & 24.7 & 0.00 & $\mathrm{TiO}_{2}+\mathrm{Ti}_{4} \mathrm{O}_{7}+\mathrm{FeTiO}_{3}+\mathrm{Fe}+\mathrm{C}$ \\
\hline $623-1233$ & 20.9 & 0.0 & 28.6 & 0.00 & $\mathrm{TiO}_{2}+\mathrm{Ti}_{3} \mathrm{O}_{5}+\mathrm{Fe}+\mathrm{C}$ \\
\hline $623-1363$ & 9.9 & 5.5 & 70.6 & 60.7 & $\mathrm{TiO}_{x} \mathrm{C}_{y} \mathrm{~N}_{z}+\mathrm{Ti}_{3} \mathrm{O}_{5}+\mathrm{Fe}+\mathrm{C}$ \\
\hline $623-1533$ & 4.9 & 7.2 & 86.6 & 68.6 & $\mathrm{TiO}_{0.27} \mathrm{C}_{0.05} \mathrm{~N}_{0.69}+\mathrm{Fe}+\mathrm{C}$ \\
\hline $623-1733$ & 1.3 & 8.5 & 96.7 & 75.4 & $\mathrm{TiO}_{0.07} \mathrm{C}_{0.18} \mathrm{~N}_{0.75}+\mathrm{Fe}+\mathrm{C}$ \\
\hline $623-1873$ & 0.2 & 9.5 & 99.5 & 75.7 & $\mathrm{TiO}_{0.01} \mathrm{C}_{0.23} \mathrm{~N}_{0.76}+\mathrm{Fe}+\mathrm{C}$ \\
\hline $623-1873^{*}$ & 15.2 & 3.3 & 64.4 & 28.4 & $\mathrm{Ti}_{3} \mathrm{O}_{5}+\mathrm{Fe}+\mathrm{TiO}_{x} \mathrm{~N}_{1-\mathrm{x}}$ \\
\hline
\end{tabular}

* Reduced in absence of carbon.

Table 1: LECO analysis and phase composition of primary ilmenite after temperature programmed reduction to different temperatures in the $\mathrm{H}_{2}-\mathrm{N}_{2}$ gas mixture. 




Fig. 4: Temperature programmed reduction of synthetic rutile in the $\mathrm{H}_{2}-\mathrm{N}_{2}$ gas mixture. Temperature was ramped from 623 to $1873 \mathrm{~K}$ at $2 \mathrm{~K} / \mathrm{min}$. Samples in the highlighted points were examined by LECO and XRD.

metallic iron; titania was converted to $\mathrm{Ti}_{3} \mathrm{O}_{5}$ and $\mathrm{TiO}_{\mathrm{x}} \mathrm{N}_{1 \mathrm{x}}$, although in a small amount (nitrogen content was 3.3 mass\%).

Secondary ilmenite and HYTI70 exhibited a similar reduction behavior to the primary ilmenite.

TPR of synthetic rutile was studied with the carbon to oxygen molar ratio of 1.30 and 1.45. In the first case, carbon was taken with slight deficit relative to carbon needed for conversion of titania to titanium carbide. TPR curves obtained in the reduction of synthetic rutile in the $\mathrm{H}_{2}-\mathrm{N}_{2}$ gas mixture are presented in Figure 4. Reduction rate was higher for higher carbon to oxygen ratio. $\mathrm{H}_{2} \mathrm{O}$ evolution was observed only at low temperature as a result of removal of absorbed water. Iron in synthetic rutile was in the metallic state; reduction of rutile to titanium suboxides at temperatures below $1123 \mathrm{~K}$ was insignificant. CO evolution started at $1028 \mathrm{~K}$. The peak of $\mathrm{CO}$ evolution was observed at $1453 \mathrm{~K}$ for C:O ratio 1.45 and $1543 \mathrm{~K}$ for C:O ratio 1.30. $\mathrm{CO}$ evolution peak was higher for $\mathrm{C}: \mathrm{O}=1.45$

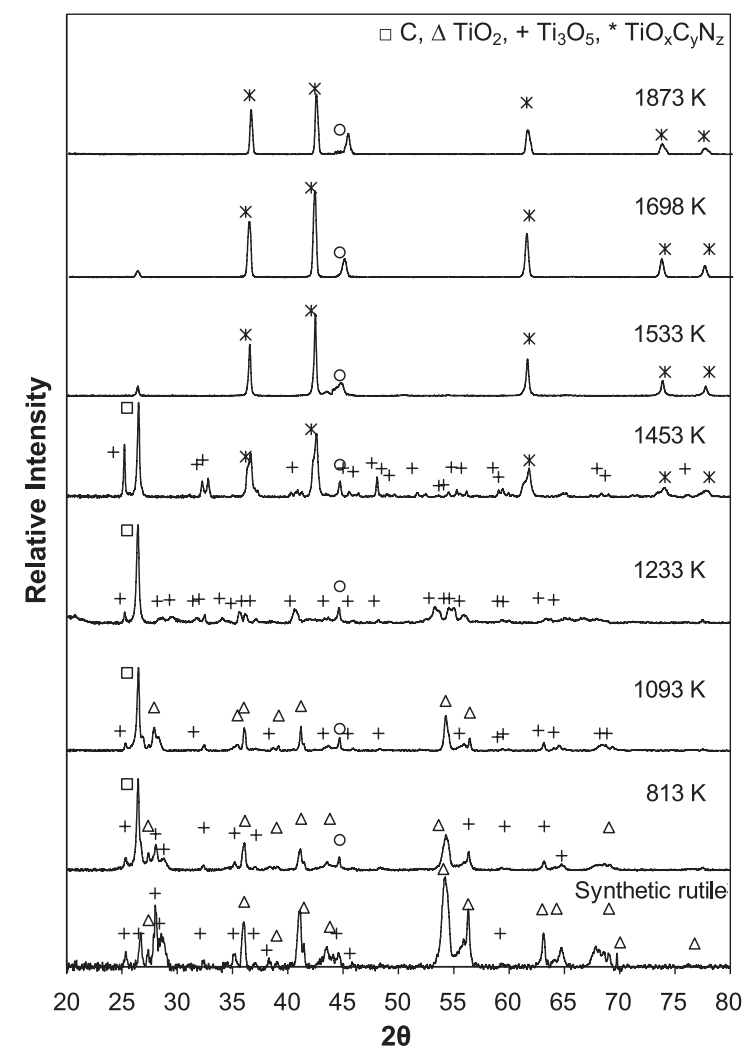

Fig. 5: XRD patterns of synthetic rutile in the progress of temperature programmed reduction in the $\mathrm{H}_{2}-\mathrm{N}_{2}$ gas mixture to the temperatures labeled in Figure 3.

(oxygen removal rate was $0.39 \mathrm{~mol} . \mathrm{kg}^{-1} \cdot \mathrm{min}^{-1}$ ) in comparison with $\mathrm{C}: \mathrm{O}=1.30\left(0.28 \mathrm{~mol} . \mathrm{kg}^{-1} \cdot \mathrm{min}^{-1}\right)$. XRD analysis of samples of synthetic rutile identified in Figure 4 is shown in Figure 5.

LECO analysis and phase composition of reduced synthetic rutile are presented in Table 2 . The change of carbon to oxygen molar ratio had a dramatic effect on the extent of nitridation $\left(\mathrm{X}_{\mathrm{N}}\right)$; it increased from $40 \%$ to $76 \%$ when

\begin{tabular}{|c|c|c|c|c|c|}
\hline Temperature, $\mathbf{K}$ & Oxygen, mass\% & Nitrogen, mass $\%$ & $X, \%$ & $X_{N}, \%$ & Phases \\
\hline 298 & 27.7 & 0.0 & 0.0 & 0.0 & $\mathrm{TiO}_{2}+\mathrm{Ti}_{3} \mathrm{O}_{5}$ \\
\hline $623-813$ & 27.5 & 0.0 & 1.6 & 0.0 & $\mathrm{Fe}+\mathrm{Ti}_{3} \mathrm{O}_{5}+\mathrm{TiO}_{2}+\mathrm{C}$ \\
\hline $623-1193$ & 27.4 & 0.0 & 4.4 & 0.0 & $\mathrm{Fe}+\mathrm{TiO}_{2}+\mathrm{Ti}_{3} \mathrm{O}_{5}+\mathrm{C}$ \\
\hline $623-1233$ & 26.7 & 0.0 & 9.7 & 0.0 & $\mathrm{Fe}+\mathrm{TiO}_{2}+\mathrm{Ti}_{3} \mathrm{O}_{5}+\mathrm{C}$ \\
\hline $623-1453$ & 15.6 & 5.9 & 63.7 & 42.0 & $\mathrm{Fe}+\mathrm{TiO}_{\mathrm{x}} \mathrm{C}_{\mathrm{y}} \mathrm{N}_{\mathrm{z}}+\mathrm{Ti}_{3} \mathrm{O}_{5}+\mathrm{C}$ \\
\hline $623-1533$ & 2.4 & 14.3 & 94.6 & 85.9 & $\mathrm{Fe}+\mathrm{TiO}_{0.11} \mathrm{C}_{0.03} \mathrm{~N}_{0.86}+\mathrm{C}$ \\
\hline $623-1698$ & 0.5 & 14.2 & 98.9 & 78.9 & $\mathrm{Fe}+\mathrm{TiO}_{0.02} \mathrm{C}_{0.04} \mathrm{~N}_{0.94}+\mathrm{C}$ \\
\hline $623-1873$ & 0.2 & 14.1 & 99.6 & 75.6 & $\mathrm{Fe}+\mathrm{TiO}_{0.01} \mathrm{C}_{0.06} \mathrm{~N}_{0.93}+\mathrm{C}$ \\
\hline $\begin{array}{l}623-1873 \\
(C: 0=1.30)\end{array}$ & 2.4 & 8.2 & 95.4 & 39.9 & $\mathrm{Fe}+\mathrm{TiO}_{0.09} \mathrm{C}_{0.51} \mathrm{~N}_{0.40}$ \\
\hline
\end{tabular}

Table 2: LECO analysis and phase composition of synthetic rutile after temperature programmed reduction to different temperatures in the $\mathrm{H}_{2}-\mathrm{N}_{2}$ gas mixture $(\mathrm{C}: \mathrm{O}=1.45)$ 
carbon to oxygen ratio increased from 1.30 to 1.45 . This was similar to the reduction of pure rutile. $\mathrm{Ti}(\mathrm{O}, \mathrm{C}, \mathrm{N})$ phase was detected in a sample heated to $1453 \mathrm{~K}$ whereas $\mathrm{Ti}(\mathrm{O}, \mathrm{C}, \mathrm{N})$ phase in the reduction of pure rutile appeared above $1533 \mathrm{~K}$. As the temperature increased, extent of reduction and nitridation increased.

\subsection{Temperature programmed reduction in nitrogen}

Reduction curves obtained in the TPR of ilmenite concentrates and synthetic rutile in nitrogen are given in Figure 6. Contrary to the results obtained in the TPR experiments in the $\mathrm{H}_{2}-\mathrm{N}_{2}$ gas mixture, reduction of synthetic rutile was the fastest, while the reduction of primary ilmenite was the slowest. Two distinct CO peaks were observed, the first primary peak at $1523 \mathrm{~K}$, and the second at $1773 \mathrm{~K}$.

XRD analysis of samples obtained in the TPR in nitrogen showed that reduction of ilmenite concentrates in nitrogen in the TPR experiments was incomplete. Titanium suboxides were not observed in the XRD spectra



Fig. 6: Temperature programmed reduction of ilmenite concentrates and synthetic rutile in $\mathrm{N}_{2}$. The temperature was ramped from 673 to $1873 \mathrm{~K}$ at $2 \mathrm{~K} / \mathrm{min}$. of synthetic rutile reduced with excess carbon. Table 3 presents LECO analysis and phase composition of these samples. Extent of nitridation $\left(\mathrm{X}_{\mathrm{N}}\right)$ decreased while extent of reduction $(\mathrm{X})$ increased with increasing grade of ilmenite. The highest $\mathrm{X}$ and $\mathrm{X}_{\mathrm{N}}$ values were obtained for synthetic rutile. XRD analysis detected $\mathrm{Ti}_{3} \mathrm{O}_{5}$ in primary, secondary and HYTI70 ilmenite concentrates at $1873 \mathrm{~K}$.

\subsection{Isothermal reduction of ilmenite concentrates}

Phase development was studied in the progress of reduction of ilmenite concentrates in the $\mathrm{H}_{2}-\mathrm{N}_{2}$ gas mixture (50 vol $\% \mathrm{H}_{2}$ ) at $1373 \mathrm{~K}$ and in nitrogen at $1573 \mathrm{~K}$. XRD spectra of samples of primary ilmenite in the progress of reduction in the $\mathrm{H}_{2}-\mathrm{N}_{2}$ gas mixture are presented in Figure 7. LECO analysis and phase composition of these samples are given in Table 4. Reduction of iron oxides was fast; the XRD spectrum of the sample reduced for 13 minutes identified $\mathrm{Ti}_{3} \mathrm{O}_{5}, \mathrm{Ti}_{5} \mathrm{O}_{9}, \mathrm{Ti}_{4} \mathrm{O}_{7}$ and metallic iron. Titanium oxycarbonitride was detected in the reduced sample after 17 min reaction. $\mathrm{Ti}_{5} \mathrm{O}_{9}, \mathrm{Ti}_{4} \mathrm{O}_{7}$ disappeared from the XRD spectra after 20 min reduction; while $\mathrm{Ti}_{3} \mathrm{O}_{5}$ was still detected in the sample reduced for $60 \mathrm{~min}$. With the extension of reaction to $100 \mathrm{~min}$ and further, the phases detected by XRD were titanium oxycarbonitride, iron and excess graphite. Extent of reduction and nitridation increased with time, while concentration of TiC in the oxycarbonitride decreased.

Reduction of secondary and HYTI70 ilmenite in the $\mathrm{H}_{2}-\mathrm{N}_{2}$ gas mixture and phase development at $1373 \mathrm{~K}$ were similar to those observed for the primary ilmenite.

Phase development in the progress of reduction of primary ilmenite in nitrogen at $1573 \mathrm{~K}$ is illustrated by the XRD spectra in Figure 8; results of LECO analysis and phase composition are given in Table 5 . The reduction in nitrogen was much slower compared to the reduction in the $\mathrm{H}_{2}-\mathrm{N}_{2}$ gas mixture. Titanium oxycarbonitride was

\begin{tabular}{|c|c|c|c|c|c|}
\hline Concentrate & Oxygen, mass $\%$ & Nitrogen, mass \% & $\mathrm{X}, \%$ & $X_{N}, \%$ & Phases \\
\hline Primary ilmenite & 11.5 & 5.04 & 69.6 & 49.4 & $\mathrm{Fe}+\mathrm{Ti}_{3} \mathrm{O}_{5}+\mathrm{TiO}_{x} \mathrm{C}_{\mathrm{y}} \mathrm{N}_{\mathrm{z}}+\mathrm{C}$ \\
\hline Secondary ilmenite & 10.6 & 5.2 & 75.7 & 46.1 & $\mathrm{Fe}+\mathrm{Ti}_{3} \mathrm{O}_{5}+\mathrm{TiO}_{x} \mathrm{C}_{\mathrm{y}} \mathrm{N}_{z}+\mathrm{C}$ \\
\hline HYTI70 & 10.3 & 5.3 & 79.7 & 39.2 & $\mathrm{Fe}+\mathrm{Ti}_{3} \mathrm{O}_{5}+\mathrm{TiO}_{\mathrm{x}} \mathrm{C}_{\mathrm{y}} \mathrm{N}_{z}+\mathrm{C}$ \\
\hline $\begin{array}{l}\text { Synthetic rutile } \\
(\mathrm{C}: 0=1.30)\end{array}$ & 5.6 & 14.0 & 85.5 & 93.7 & $\mathrm{Ti}_{3} \mathrm{O}_{5}+\mathrm{TiO}_{\mathrm{x}} \mathrm{C}_{\mathrm{y}} \mathrm{N}_{\mathrm{z}}+\mathrm{C}$ \\
\hline $\begin{array}{l}\text { Synthetic rutile } \\
(C: 0=1.45)\end{array}$ & 1.6 & 14.7 & 96.2 & 88.1 & $\mathrm{TiO}_{0.08} \mathrm{C}_{0.04} \mathrm{~N}_{0.88}+\mathrm{Fe}+\mathrm{C}$ \\
\hline
\end{tabular}

Table 3: LECO analysis and phase composition of ilmenite concentrates and synthetic rutile subjected to temperature programmed reduction in nitrogen. 


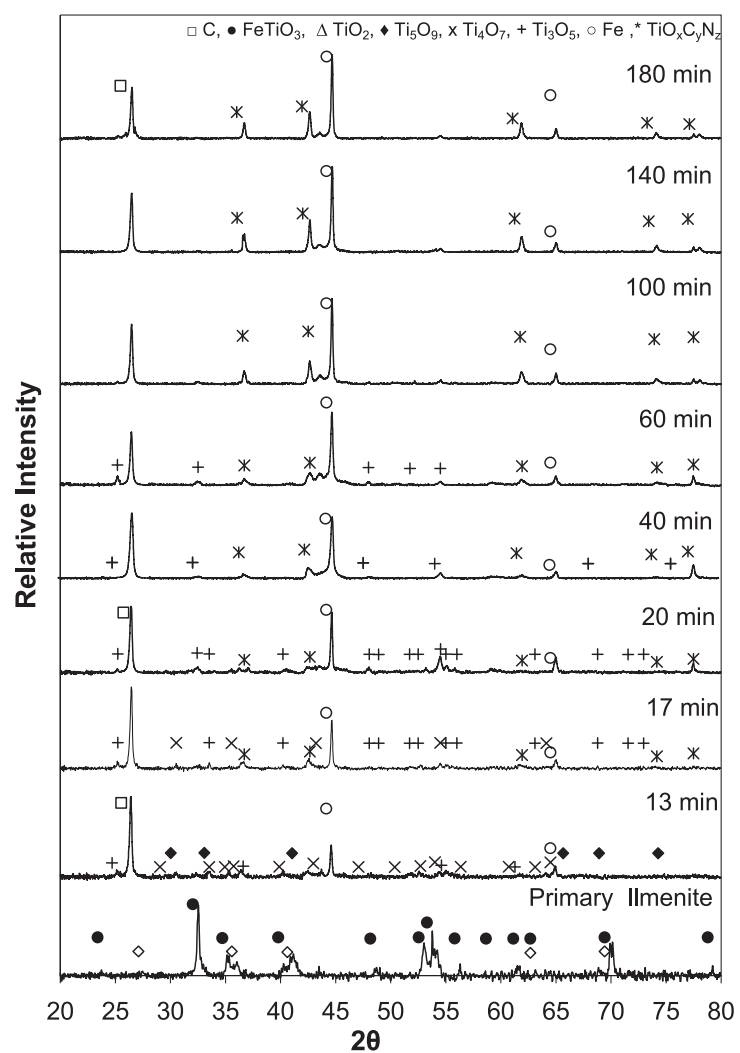

Fig. 7: XRD patterns of primary ilmenite in the progress of reduction in the $\mathrm{H}_{2}-\mathrm{N}_{2}$ gas mixture at $1373 \mathrm{~K}$.

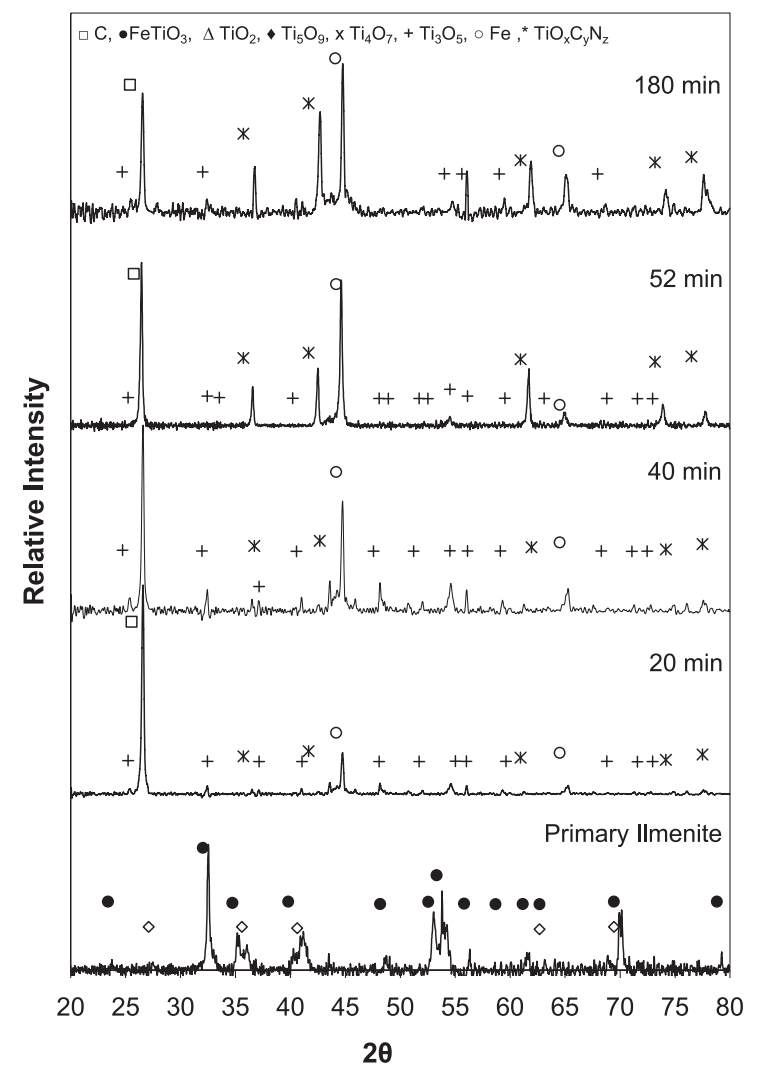

Fig. 8: XRD patterns of primary ilmenite in the progress of reduction in nitrogen at $1573 \mathrm{~K}$.

\begin{tabular}{|c|c|c|c|c|c|}
\hline Time, min. & Oxygen, mass $\%$ & Nitrogen, mass $\%$ & $\mathrm{X}, \%$ & $X_{N}, \%$ & Phases \\
\hline 0 & 25.1 & 0.0 & 0.0 & 0.0 & $\mathrm{FeTiO}_{3}+\mathrm{Fe}_{2} \mathrm{Ti}_{3} \mathrm{O}_{9}$ \\
\hline 13 & 21.2 & 0.0 & 20.9 & 0.0 & $\mathrm{Ti}_{3} \mathrm{O}_{5}+\mathrm{Ti}_{5} \mathrm{O}_{9}+\mathrm{Ti}_{4} \mathrm{O}_{7}+\mathrm{Fe}+\mathrm{C}$ \\
\hline 17 & 15.0 & 0.0 & 50.8 & 0.0 & $\mathrm{Ti}_{3} \mathrm{O}_{5}+\mathrm{Ti}_{4} \mathrm{O}_{7}+\mathrm{TiO}_{x} \mathrm{C}_{\mathrm{y}} \mathrm{N}_{\mathrm{z}}+\mathrm{Fe}+\mathrm{C}$ \\
\hline 20 & 13.3 & 0.3 & 57.5 & 4.1 & $\mathrm{TiO}_{x} \mathrm{C}_{y} \mathrm{~N}_{z}+\mathrm{Ti}_{3} \mathrm{O}_{5}+\mathrm{Fe}+\mathrm{C}$ \\
\hline 40 & 10.8 & 3.1 & 66.5 & 36.2 & $\mathrm{TiO}_{x} \mathrm{C}_{\mathrm{y}} \mathrm{N}_{z}+\mathrm{Ti}_{3} \mathrm{O}_{5}+\mathrm{Fe}+\mathrm{C}$ \\
\hline 60 & 7.2 & 4.4 & 79.7 & 47.3 & $\mathrm{TiO}_{x} \mathrm{C}_{\mathrm{y}} \mathrm{N}_{z}+\mathrm{Ti}_{3} \mathrm{O}_{5}+\mathrm{Fe}+\mathrm{C}$ \\
\hline 100 & 5.6 & 6.5 & 85.2 & 67.1 & $\mathrm{Ti}_{0.30} \mathrm{C}_{0.03} \mathrm{~N}_{0.67}+\mathrm{Fe}+\mathrm{C}$ \\
\hline 140 & 5.0 & 7.2 & 87.3 & 72.9 & $\mathrm{Ti}_{0.25} \mathrm{C}_{0.02} \mathrm{~N}_{0.73}+\mathrm{Fe}+\mathrm{C}$ \\
\hline 180 & 4.9 & 8.1 & 88.6 & 76.5 & $\mathrm{Ti}_{0.23} \mathrm{C}_{0.01} \mathrm{~N}_{0.76}+\mathrm{Fe}+\mathrm{C}$ \\
\hline
\end{tabular}

Table 4: LECO analysis and phase composition of primary ilmenite in the progress of reduction in the $\mathrm{H}_{2}-\mathrm{N}_{2}$ gas mixture at $1373 \mathrm{~K}$.

\begin{tabular}{|c|c|c|c|c|c|}
\hline Time, $\min$ & Oxygen, mass $\%$ & Nitrogen, mass $\%$ & $x, \%$ & $X_{N}, \%$ & Phases \\
\hline 0 & 25.1 & 0.00 & 0.0 & 0.00 & $\mathrm{FeTiO}_{3}+\mathrm{Fe}_{2} \mathrm{Ti}_{3} \mathrm{O}_{9}+\mathrm{C}$ \\
\hline 20 & 21.5 & 0.00 & 22.8 & 0.00 & $\mathrm{Fe}+\mathrm{Ti}_{3} \mathrm{O}_{5}+\mathrm{C}$ \\
\hline 40 & 18.8 & 0.2 & 41.5 & 1.8 & $\mathrm{Fe}+\mathrm{TiO}_{x} \mathrm{C}_{\mathrm{y}} \mathrm{N}_{\mathrm{z}}+\mathrm{Ti}_{3} \mathrm{O}_{5}+\mathrm{C}$ \\
\hline 52 & 17.1 & 2.0 & 49.1 & 21.9 & $\mathrm{Fe}+\mathrm{TiO}_{x} \mathrm{C}_{y} \mathrm{~N}_{z}+\mathrm{Ti}_{3} \mathrm{O}_{5}+\mathrm{C}$ \\
\hline 180 & 10.3 & 3.9 & 68.9 & 43.6 & $\mathrm{Fe}+\mathrm{TiO}_{\mathrm{x}} \mathrm{C}_{\mathrm{y}} \mathrm{N}_{\mathrm{z}}+\mathrm{Ti}_{3} \mathrm{O}_{5}+\mathrm{C}$ \\
\hline
\end{tabular}

Table 5: LECO analysis and phase composition of primary ilmenite in the progress of reduction in nitrogen at $1573 \mathrm{~K}$. 
detected by XRD analysis after 40 min reduction; conversion of $\mathrm{Ti}_{3} \mathrm{O}_{5}$ to $\mathrm{Ti}(\mathrm{O}, \mathrm{C}, \mathrm{N})$ in nitrogen at $1573 \mathrm{~K}$ was not completed in 3 hours.

\section{Discussion}

The major phases in primary ilmenite were ilmenite $\mathrm{FeTiO}_{3}$ and pseudorutile $\mathrm{Fe}_{2} \mathrm{Ti}_{3} \mathrm{O}_{9}$, while secondary and HYTI70 ilmenites also contained rutile. Titania was the major phase in the synthetic rutile. Reduction of ilmenites started with conversion of pseudorutile into ilmenite which was further reduced to titania and metallic iron [6]. Further reduction of titania followed the same sequence as pure rutile $[9,10]$.

Carbothermal reduction of pseudorutile and ilmenite in nitrogen proceeded through the gas phase by reaction with $\mathrm{CO}$ with formation of $\mathrm{CO}_{2}$ as presented by Reactions (1) and (2).

$$
\begin{gathered}
\mathrm{Fe}_{2} \mathrm{Ti}_{3} \mathrm{O}_{9}+\mathrm{CO} \rightarrow 2 \mathrm{FeTiO}_{3}+\mathrm{TiO}_{2}+\mathrm{CO}_{2} \\
\mathrm{FeTiO}_{3}+\mathrm{CO} \rightarrow \mathrm{Fe}+\mathrm{TiO}_{2}+\mathrm{CO}_{2}
\end{gathered}
$$

CO was regenerated via Boudouard Reaction (3).

$$
\mathrm{CO}_{2}+\mathrm{C}=2 \mathrm{CO}
$$

When ilmenite was reduced in the $\mathrm{H}_{2}-\mathrm{N}_{2}$ gas mixture, iron oxides in pseudorutile and ilmenite were reduced by hydrogen (Reactions (4) and (5)):

$$
\begin{gathered}
\mathrm{Fe}_{2} \mathrm{Ti}_{3} \mathrm{O}_{9}+\mathrm{H}_{2} \rightarrow 2 \mathrm{FeTiO}_{3}+\mathrm{TiO}_{2}+\mathrm{H}_{2} \mathrm{O} \\
\mathrm{FeTiO}_{3}+\mathrm{H}_{2} \rightarrow \mathrm{Fe}+\mathrm{TiO}_{2}+\mathrm{H}_{2} \mathrm{O}
\end{gathered}
$$

Conversion of $\mathrm{TiO}_{2}$ to titanium oxycarbonitride followed the path of conversion of rutile presented elsewhere [9, 10]. Reduction of iron oxide to metallic iron and conversion of titania to titanium oxycabonitride in the $\mathrm{H}_{2}-\mathrm{N}_{2}$ gas mixture was faster than in nitrogen. The role of gas atmosphere in carbothermal reduction of rutile was discussed previously [10]. Progress of reduction of ilmenites follows the sequence:

$$
\begin{aligned}
\mathrm{Fe}_{2} \mathrm{Ti}_{3} \mathrm{O}_{9}+\mathrm{FeTiO}_{3} & \rightarrow \mathrm{FeTiO}_{3}+\mathrm{TiO}_{2} \rightarrow \mathrm{Fe}+\mathrm{TiO}_{2} \\
\rightarrow \mathrm{Fe}+\mathrm{Ti}_{3} \mathrm{O}_{5} & \rightarrow \mathrm{Fe}+\mathrm{TiO}_{\mathrm{x}} \mathrm{C}_{\mathrm{y}} \mathrm{N}_{\mathrm{z}}
\end{aligned}
$$

Reduction behaviour of ilmenites of different grades was similar to that observed in the synthesis of titanium oxy- carbide by carbothermal reduction of ilmenites in hydrogen and helium [11]. The reduction rate increased with decreasing ilmenite grade in the reduction in the $\mathrm{H}_{2}$ or in $\mathrm{H}_{2}-\mathrm{N}_{2}$ gas mixture, and reduction rate decreased with decreasing ilmenite grade when reduction was in inert gas atmosphere or in nitrogen. Difference in the reduction of ilmenites of different grades was attributed to differences in iron content and morphology.

Optical and SEM analyses showed [11] that ilmenite concentrate of a higher grade had a higher porosity as a result of ilmenite weathering. The degree of weathering and particle porosity were the highest for synthetic rutile and lowest for primary ilmenite.

The morphology of ilmenite concentrates changed in the process of reduction; this change depended on the concentrate grade and the gas atmosphere. Reduction of iron oxides from ilmenite concentrates by hydrogen was very fast; fine iron grains were formed and a porous structure within the titanium oxide matrix was developed. Reduction of ilmenites in inert gases and nitrogen resulted in formation of coarse grains of metallic iron with a denser particle structure in comparison with reduction in $\mathrm{H}_{2}$ or $\mathrm{H}_{2}-\mathrm{N}_{2}$ gases. Originally most dense structure of primary ilmenite with the highest concentration of iron oxides, after reduction of iron oxides by hydrogen converted to the least dense structure. This positively affected the rate of conversion of titania to oxycarbide/oxycarbonitride. Reduction of synthetic rutile with a small amount of iron oxides was not affected. The higher was a content of iron oxide in the ilmenite concentrate, the higher was the rate of reduction in hydrogen.

Reduction of iron oxides from ilmenites in inert gases or nitrogen was relatively slow and proceeded at higher temperatures, producing coarse iron grains. In this case, the change in the particle structure was not significant; the original particle porosity was the major factor defining the conversion of ilmenite to iron and titanium oxycarbide/ oxycarbonitride. This conversion was the fastest in the case of synthetic rutile which had the highest porosity.

\section{Conclusions}

Phase development in carbothermal reduction and nitridation of ilmenite concentrates and synthetic rutile was studied in temperature programmed reduction and isothermal experiments in the $\mathrm{H}_{2}-\mathrm{N}_{2}$ gas mixture and in nitrogen. Ilmenite concentrates and synthetic rutile were reduced to metallic iron and titanium oxycarbonitride. The rate and extent of reduction and nitridation were 
affected by temperature, gas atmosphere, composition of the ilmenite concentrates (concentration of iron and titanium oxides) and concentrate morphology.

Carbothermal reduction of all titanium sources was faster in the $\mathrm{H}_{2}-\mathrm{N}_{2}$ gas mixture than in nitrogen. Rate and extent of conversion of titanium oxides to $\mathrm{Ti}(\mathrm{O}, \mathrm{C}, \mathrm{N})$ increased with increasing temperature.

Reduction of ilmenite concentrates in the $\mathrm{H}_{2}-\mathrm{N}_{2}$ gas mixture started with fast reduction of iron oxides in pseudorutile and ilmenite to metallic iron by hydrogen.

Progress of reduction of ilmenites followed the sequence:

$$
\begin{aligned}
\mathrm{Fe}_{2} \mathrm{Ti}_{3} \mathrm{O}_{9}+\mathrm{FeTiO}_{3} & \rightarrow \mathrm{FeTiO}_{3}+\mathrm{TiO}_{2} \rightarrow \mathrm{Fe}+\mathrm{TiO}_{2} \\
\rightarrow \mathrm{Fe}+\mathrm{Ti}_{3} \mathrm{O}_{5} & \rightarrow \mathrm{Fe}+\mathrm{TiO}_{\mathrm{x}} \mathrm{C}_{\mathrm{y}} \mathrm{N}_{\mathrm{z}}
\end{aligned}
$$

In the temperature programmed and isothermal experiments in the $\mathrm{H}_{2}-\mathrm{N}_{2}$ gas mixture, reduction rate increased with decreasing ilmenite grade; reduction of primary ilmenite was the fastest, while reduction of synthetic rutile was the slowest. The rate of reduction in nitrogen increased with increasing ilmenite grade; reduction of synthetic rutile was the fastest, while the reduction of primary ilmenite was the slowest. Difference in the reduction behaviour of ilmenites of different grades was attributed to differences in iron content in the ilmenite concentrate and concentrate morphology, which changed in the progress of reduction.

\section{Acknowledgements}

This research was supported under Australian Research Council's Discovery Projects funding scheme. Professor Ostrovski is the recipient of an Australian Research Council Professorial Fellowship (project number DP0771059). Ilmenite concentrates were supplied by Iluka Resources Limited.

Received: April 25, 2012. Accepted: July 9, 2012.

\section{References}

[1] G.J. Mostert, B.R. Rohrmann, R.J. Wedlake and R.C. Baxter, Ger. Offen. DE 4124547 (1992).

[2] G.J. Mostert, B.R. Rohrmann, R.J. Wedlake and R.C. Baxter, Brit. UK Pat. Appl. GB 2246345 (1992).

[3] N. Kanari, I. Gaballah and E. Allain, Metallurgical and Materials Transactions B, 30B, 577-587 (1999).

[4] K.D. Hitching and E.G. Kelly, Trans. Instn Min. Metall. (Sect. C: Mineral Process. Extr. Metall.), 91, C97-C99 (1982).

[5] W.L. Hunter, J.E. Mauser and W.A. Stickney, TMS/AIME Preprint A73-18, 257-270 (1973).

[6] S.A. Rezan, G. Zhang and O. Ostrovski, ISIJ International, 52 (3), 363-368 (2012).

[7] G. Zhang and O. Ostrovski: Metallurgical and Materials Transactions B, 31B (1), 129-139 (2000).

[8] M.A.R. Dewan, G. Zhang and O. Ostrovski, Metallurgical and Materials Transactions B, 40B (1), 62-69 (2009).

[9] S.A. Rezan, G. Zhang and O. Ostrovski, Journal of American Ceramic Society, 94 (11), 3804-3811 (2011).

[10] S.A. Rezan, G. Zhang and O. Ostrovski, Metallurgical and Materials Transactions B, 43B (1), 73-81 (2012).

[11] M.A.R. Dewan, G. Zhang and O. Ostrovski, ISIJ International, 50 (5), 647-657 (2010). 